\title{
Identification of The Main Water Quality Parameters for Monitoring and Evaluating Watershed Health
}

\author{
Pranatasari Dyah Susanti ${ }^{1}$ and Nining Wahyuningrum ${ }^{2}$ \\ 1,2Watershed Management Technology Center (WMTC), Kartasura, Surakarta, Jawa Tengah, Indonesia.
}

Received: 2019-07-28 Accepted: $2020-02-07$

\section{Keywords: water quality; dominant parameters; watershed}

Correspondent email: pranatasari_santi@yahoo.com

\begin{abstract}
Water quality is one of the crucial parameters in monitoring and evaluating watersheds. A large number of parameters causes the monitoring and evaluation of watershed performance to be less efficient and costly. This study aims to determine the main parameters as a method of simplifying water quality observation parameters by producing equations that can be used to predict the level of pollution of a nonpoint source pollutant (watershed). A sampling of surface water was carried out by purposive sampling at several outlets located in the Brantas and Upper Solo watersheds. The research parameters analysed were: TSS, TDS, BOD, COD, Phenol, Free Chlorineine, Sulfide, Arsenic, Fe, Pb, Phosphate, Nitrate, Nitrite, Detergent, Turbidity and E. Coli. The results of the analysis of water quality are used to calculate the value of the Pollution Index (PI) according to the Decree of the Minister of Environment No. 115 of 2003 and to determine the class of water quality standards that refer to Class III water quality standards, in Government Regulation No.82 of 2001. The analysis showed that all samples were at mild to moderate pollution levels, and did not meet class III water quality standards. Multiple regression analysis produced two equations, namely: Model 1: PI = 3.952 + 91.668 Phenol and Model 2: PI $=3.086+80.167$ Phenol +0.152 BOD, with R squared values of $53 \%$ and $69.9 \%$ with a confidence level of 0.005 . Thus the prediction of pollution levels of similar watershed can be made only by using the two most influential parameters namely phenol and/or BOD alone.
\end{abstract}

2020 by the authors. Licensee Indonesian Journal of Geography, Indonesia.

政

Attribution(CC BY NC) licensehttps://creativecommons.org/licenses/by-nc/4.0/.

\section{Introduction}

A watershed is an area that is an integral part of a river and its tributaries, which functions naturally to accommodate, store and flow water that comes from rainfall to lakes or the sea, the boundary on land is the topographic separator and the boundary at the sea until the area where waters still affected by land activities (Pemerintah Republik Indonesia, 2012). Watershed management is inseparable from land use and land management. Land use that is not suitable for its designation and capabilities, and does not pay attention to the principles of soil and water conservation, will cause damage to the watershed ecosystem. Damage to watershed ecosystems in Indonesia can be seen from the many occurrences of various disasters such as floods, erosion, sedimentation, and landslides (Paimin, Sukresno, \& Purwanto, 2010). Damage to the ecosystem must be prevented by proper watershed management.

Related to water quality, some types of cover/land use can affect water quality (Effendi, Muslimah, \& Permatasari, 2018; Permatasari, Setiawan, \& Effendi, 2017; Shukla et al., 2018; Singh et al., 2017). The water quality of the river can be polluted not only in rural but also in urban areas (Shukla et al., 2018). Fertilisers are the main pollutant in agriculture area while domestics and industrial wastes mostly contribute in the urban area. Organic manure spreading in agriculture activities has negative and positive effects as well. Beside improving organic matter content of the soil, this nutrient may be carried away by runoff to the stream (Singh et al., 2017).

Based on Government Regulation of the Republic of Indonesia No. 37 of 2012 concerning Management of Watersheds, it is stated that watershed management is "Human efforts in regulating the reciprocal relationship between natural resources and humans in a watershed with all its activities, to realize the sustainability and harmony of ecosystems and increase the usefulness of natural resources for humans sustainably" (Pemerintah Republik Indonesia, 2012). Appropriate watershed management requires the support of monitoring and evaluation activities. Watershed Monitoring and evaluation is an activity to obtain a description of the entire watershed area covering various aspects such as land use, institutional socio-economic, and water management (Dirjen RLPS, 2009). Water management, especially water quality, is very crucial because it is very influential for life (Kurnaz, Mutlu, \& Uncumusaoğlu, 2016; Mutlu \& Uncumusaoğlu, 2017; Nazir et al., 2015). Observation of water quality can be conducted by analysing water samples. In the Regulation of the Director General of RLPS No. P.04 / V-SET / 2009 (P.04/2009), it has 17 parameters for monitoring water quality. The parameters are divided into 3 groups, namely physical parameters (colour, Total Dissolved Solid (TDS) and turbidity); chemical parameters ( $\mathrm{pH}$, Electrical Conductivity (EC), Nitrate, Sulphate, Phosphate, Potassium, Chlorineide, Sodium, Magnesium and Calcium); and biological parameters 
(Organic Matter (OM), Dissolved Oxygen (DO), Biological Oxygen Demand (BOD) and Chemical Oxygen Demand (COD)). Based on this regulation, the number of parameters that must be observed is very large. This parameter analysis will be very costly. Therefore, it is necessary to select parameters that are simpler while reflecting the conditions of water quality and polluting compounds. The statement is in following Basuki's finding (2015) that the number of parameters is difficult to be explained.

Apart from each element's parameter, the condition of water quality in a water body can also be seen from the Pollution Index (PI) values. PI can be used as input to assess the quality of water bodies, and also can be used as a reference in carrying out several actions to improve its quality based on its pollutants limitation. PI includes water quality parameters independently but still has meaning (Keputusan Menteri Lingkungan Hidup No. 115 Tahun 2003). This study aims to find out the main parameters that most influence water PI, which can reflect water quality in a watershed.

\section{The Methods}

\section{Location and Time}

This research was conducted in 2 watershed areas, namely Upper Solo Watershed and Brantas Watershed. The study was conducted for three years in 2015-2017. The Upper Solo and Brantas Watershed were chosen because they represent watersheds with high population densities and high rainfall intensity dominated by mineral soils such as alfisol, inceptisol, entisol, vertisol, ultisol (Jariyah, 2019; Jariyah \& Pramono, 2018; Wahyuningrum \& Basuki 2019; Wahyuningrum \& Putra 2019), thus the resulting regression equation will represent regions with similar conditions. Non-PointSource (NPS) sampling locations were at the outlets of subwatershed. The sample locations chosen represent all types of land use based on land use activities near the flow; besides this location also represents the whole activities in the whole catchment area. The results thus illustrate the impact of activities in the catchment area. This sampling method was practiced by Ding et al. (2015). Also, according to Medium Term Development Plan (Rencana Pembangunan Jangka Menengah), these two watersheds were classified as the Priority Watershed to be restored (Bappenas, 2015) and also were potentially polluted due to various types of pollutants produced by community activities, for example domestic, agricultural, industrial and other activities as stated by Roosmini et al. (2018); Darmawan, Sulardiono, \& Haeruddin (2018). The outlets of Solo and Brantas Watersheds are located 7०20'48,84'S; $111^{\circ} 07^{\prime} 25,56^{\prime \prime} \mathrm{E}$ and $7^{\circ} 26^{\prime} 50,40^{\prime \prime} \mathrm{S}$; $112^{\circ} 27^{\prime} 15,04^{\prime \prime} \mathrm{E}$, respectively. The study areas can be seen in Figure 1 .

\section{Data collection}

Land use/land cover was collected from the secondary data from BPKH (Balai Pemantapan Kawasan Hutan), which is resulted from image interpretation. DEM (Digital Elevation Model) map was used to determine the sub-watershed boundary based on the selected outlet position. Road and river network maps were obtained from the RBI (Rupa Bumi Indonesia) map. All of these spatial data were processed using ArcGIS 9.2.

The data was collected by taking surface water samples by purposive sampling at each selected sub-watershed outlet. The number of sub-watershed outlets in this study was 28, which consisted of 13 in the Upper Solo watershed and 15 in the Brantas watershed. Sampling is carried out in the wet and dry seasons. These samples were considered Non-Point Source (NPS) data. The number of samples observed was higher than the number used by Effendi \& Wardiatno (2015); Effendi (2016); Effendi, Muslimah et al. (2018); Effendi, Sabila, \& Setiawan (2018) in determining the water quality index and the correlation of land use changes on water index in Ciambulawung and Ciliwung River Basins. The number of samples used for correlation-regression analysis differed in several studies; there was no exact amount to be collected (Table 1). The number of samples in this study is considered to be sufficient, although the model obtained still requires

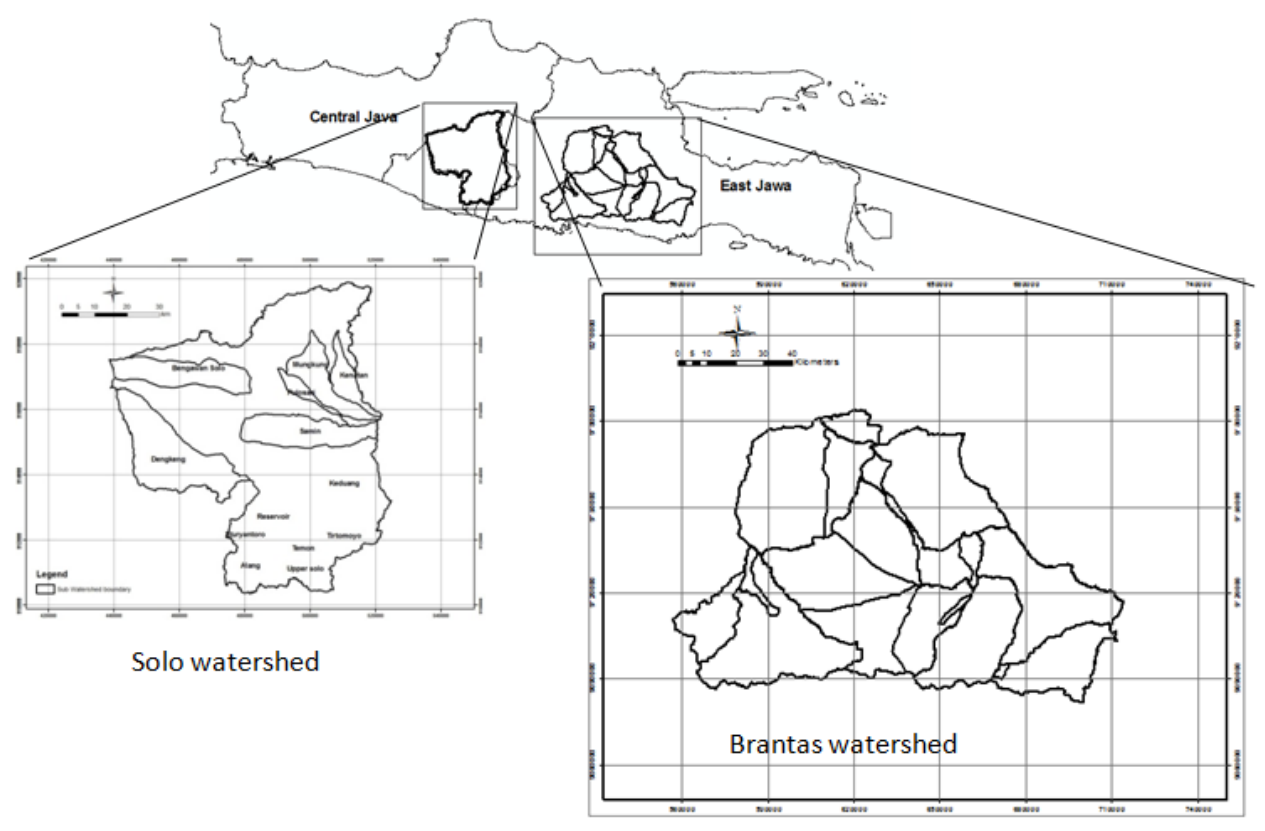

Figure 1. Study area map 
Table 1 . The number of samples used in several studies related to water quality

\begin{tabular}{llrrl}
\hline \multicolumn{1}{c}{ Watersheds } & \multicolumn{1}{c}{ Countries } & \multicolumn{1}{c}{$\begin{array}{c}\text { Total Area } \\
\text { (ha) }\end{array}$} & $\begin{array}{c}\text { Number of } \\
\text { Samples Used }\end{array}$ & \multicolumn{1}{c}{ References } \\
\hline Choaku Lake & China & $1,335,000$ & 81 & Huang, Zhan, Yan, Wu, \& Deng (2013) \\
$\begin{array}{l}\text { Jacaré-Pepira River and } \\
\text { Jacaré-Guaçu River }\end{array}$ & Brazil & Not Available & 15 & Souza, Fonseca, Libório, \& Tanaka (2013) \\
Ciambulawung & Indonesia & Not Available & 9 & Effendi \& Wardiatno (2015) \\
Upper Solo & Indonesia & Not Available & $27-32$ & Basuki (2015) \\
Dong Jiang & China & $3,534,000$ & 83 & Ding et al. (2015) \\
Grojokan Sewu & Indonesia & 1,130 & 4 & Wahyuningrum \& Pramono (2013) \\
\hline
\end{tabular}

validation using other data.

The research parameters observed were water quality both, physical, chemical, and biological, namely: Total Suspended Solid (TSS), TDS, BOD, COD, Phenol, Free Chlorineine $(\mathrm{Cl})$, Fe, Phosphate, Nitrate, Nitrite, Detergent, Turbidity and E. coli. Water quality analyses was carried out by the Laboratorium of Balai Besar Teknik Kesehatan Lingkungan dan Pengendalian Penyakit in Yogyakarta

\section{Data Analysis}

The average value of the water quality of each sample was used to calculate the PI value and class of water pollution. The guideline used is the Decree of the Minister of Environment No. 115 of 2003 concerning Guidelines for Determining the Status of Water Quality, while the water quality standard used is Government Regulation No.82 of 2001 (PP 82/2001) concerning Management of Water Quality and Water Pollution Control in Class III. This Class III, is a class with the designation of freshwater fisheries, livestock, irrigation, or other designation that requires the same quality. The use of class III is the same as the method used by (Effendi, 2016). A descriptive analysis was performed to determine the diversity of data, followed by correlation analysis of each water quality parameter with PI. The regression analysis was then performed using water quality parameters as an independent variable and PI as the dependent variable. Variables with high correlation values $(>0.5)$ were used in regression analysis. Multiple linear regression was used for the analysis, using the following equation:

$$
\mathrm{Y}=\mathrm{a}+\mathrm{b}_{1} \mathrm{X}_{1}+\mathrm{b}_{2} \mathrm{X}_{2}+\ldots .+\mathrm{b}_{\mathrm{n}} \mathrm{X}_{\mathrm{n}}+\varepsilon
$$

Where:

$\begin{array}{ccc}\mathrm{Y} & = & \mathrm{PI} \\ \mathrm{X}_{1}, \mathrm{X}_{2 \ldots} \mathrm{Xn} & & \text { Water quality parameters } \\ \mathrm{A} & = & \text { Constant } \\ \varepsilon & = & \text { Error }\end{array}$

\section{Result and Discussion}

Land use/land cover types

Some community activities such as agriculture, domestic and industries have the potential to cause pollution which results in a decrease in water quality. The results of a study conducted by Shukla et al. (2018) showed that population growth and agricultural activity were directly related to a decrease in water quality, especially BOD, DO, and E. coli. Moreover, Huang, Zhan, Yan, Wu, \& Deng (2013) found that there was a positive correlation between agricultural land with $\mathrm{DO}$ and $\mathrm{NH}_{3}-\mathrm{N}$ concentrations; this is due to the opening of the soil surface due to tillage and also because of the application of chemical fertilisers. Vegetation covers may also influence water quality, as stated by (Wahyuningrum \& Pramono, 2013). They stated that the forest area has a correlation with sodium, nitrite, TDS, sulphate and organic matter in quadratic form Wahyuningrum \& Pramono (2013). This indicates that the forest can reduce water pollution because it can function as a filter to hold nutrient-containing sediments so that it does not enter the river flow. Besides, Urban areas consisting of settlements, industrial complexes, offices, and trade areas can contribute many pollutants which have implications for the reduction of water quality because compared to other land cover types this urban area produces more wastewater (Permatasari, Setiawan, Khairiah, \& Effendi, 2017).

Information about the condition of land use/land cover is crucial, to provide an overview of the sources of pollution in a watershed. Human activities are described in the distribution of land use/land cover. Locations that have the potential pollution can be easily identified if land use/land cover distribution map is available. The water quality observed at the outlet represents the community activities based on the distribution of land cover types. Each sub-watershed has a different type of land use/land cover composition. This composition will have an impact on water quality. The types and extent of land use/land cover of each sub-watershed can be seen in Figure 4 and 5. The type of land use/land cover that has the potential pollution is seasonal crops such as rice fields and dry fields, and settlements (buildings area) (Shukla et al., 2018; Singh et al., 2017). Samples distribution and land use / land cover of the study areas can be seen in Figure 2 and Figure 3. 


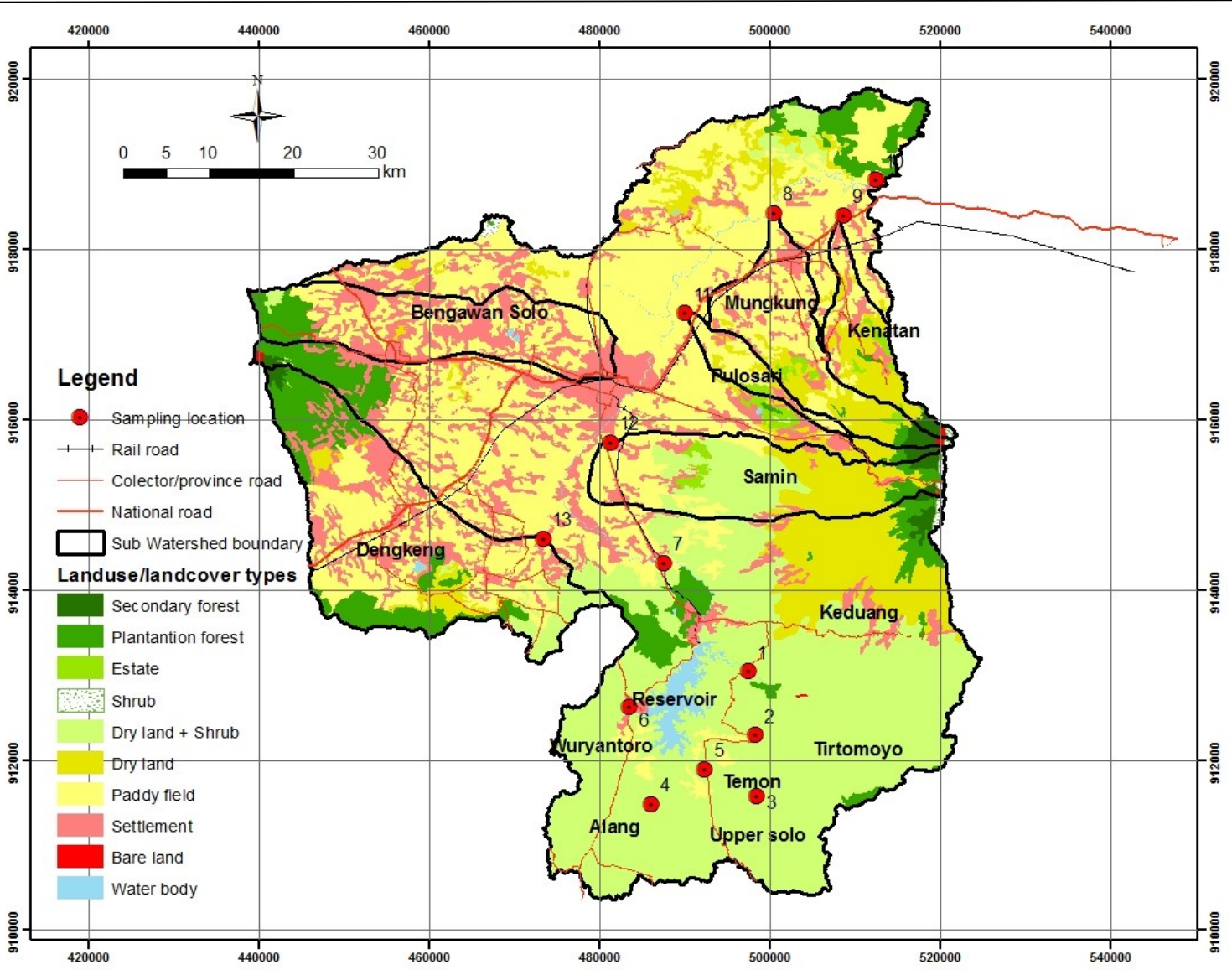

Figure 2. Distribution of Non-Point Source samples and land use/land cover of Upper Solo watershed

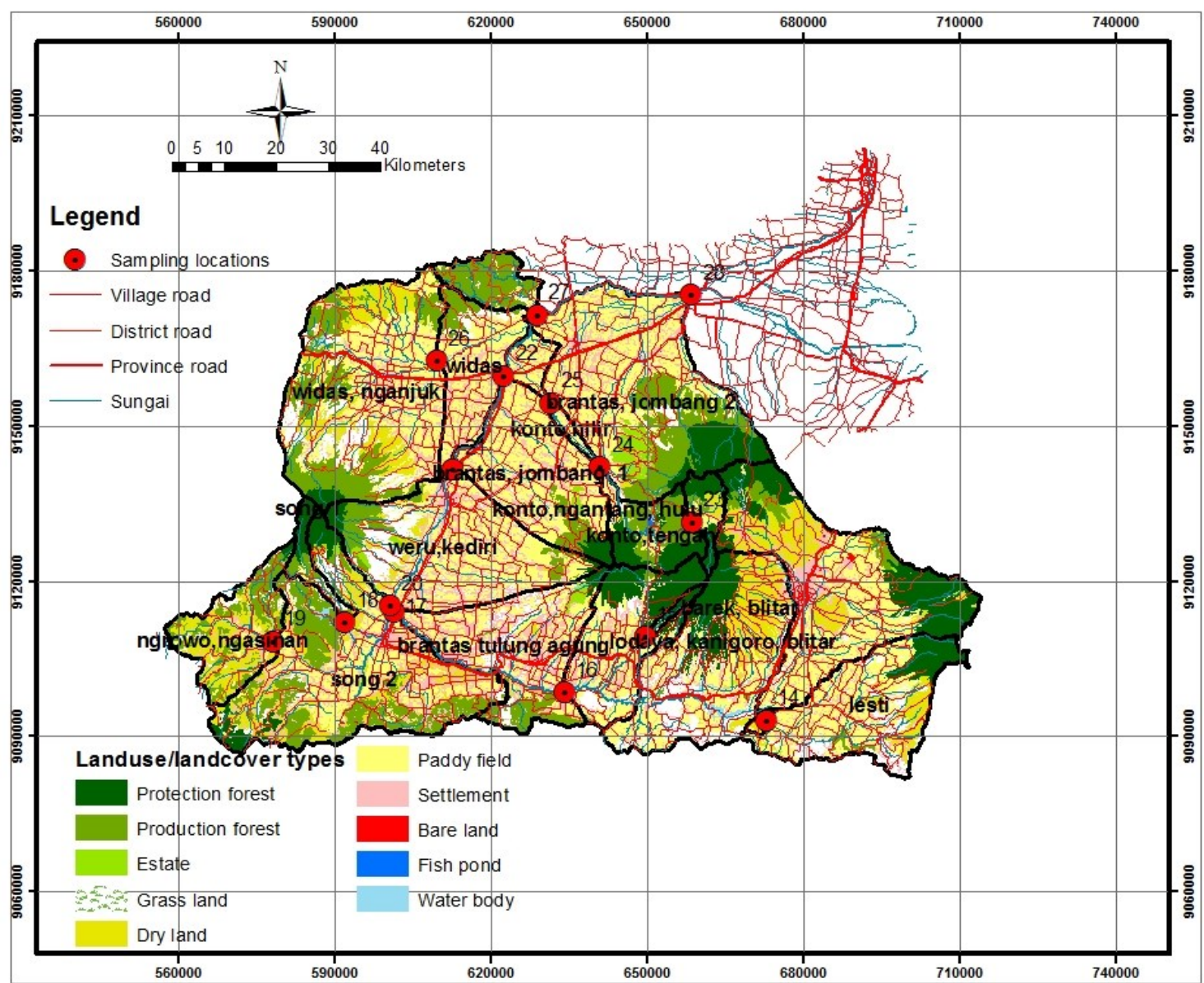

Figure 3. Distribution of Non-Point Source samples and land use/land cover of Brantas watershed 


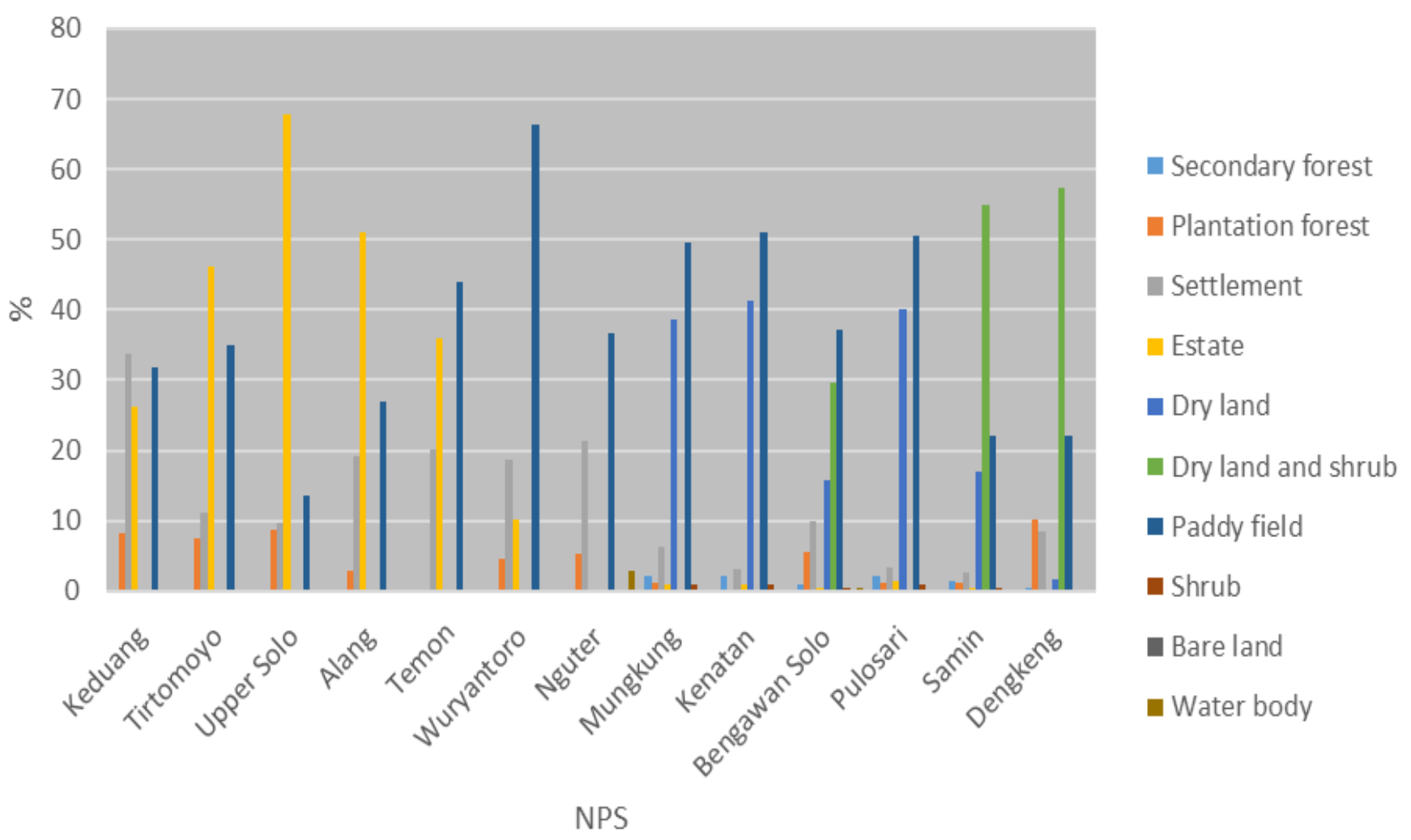

Figure 4. Percentage of land use/land cover area of each Non-Point Source in Solo watershed

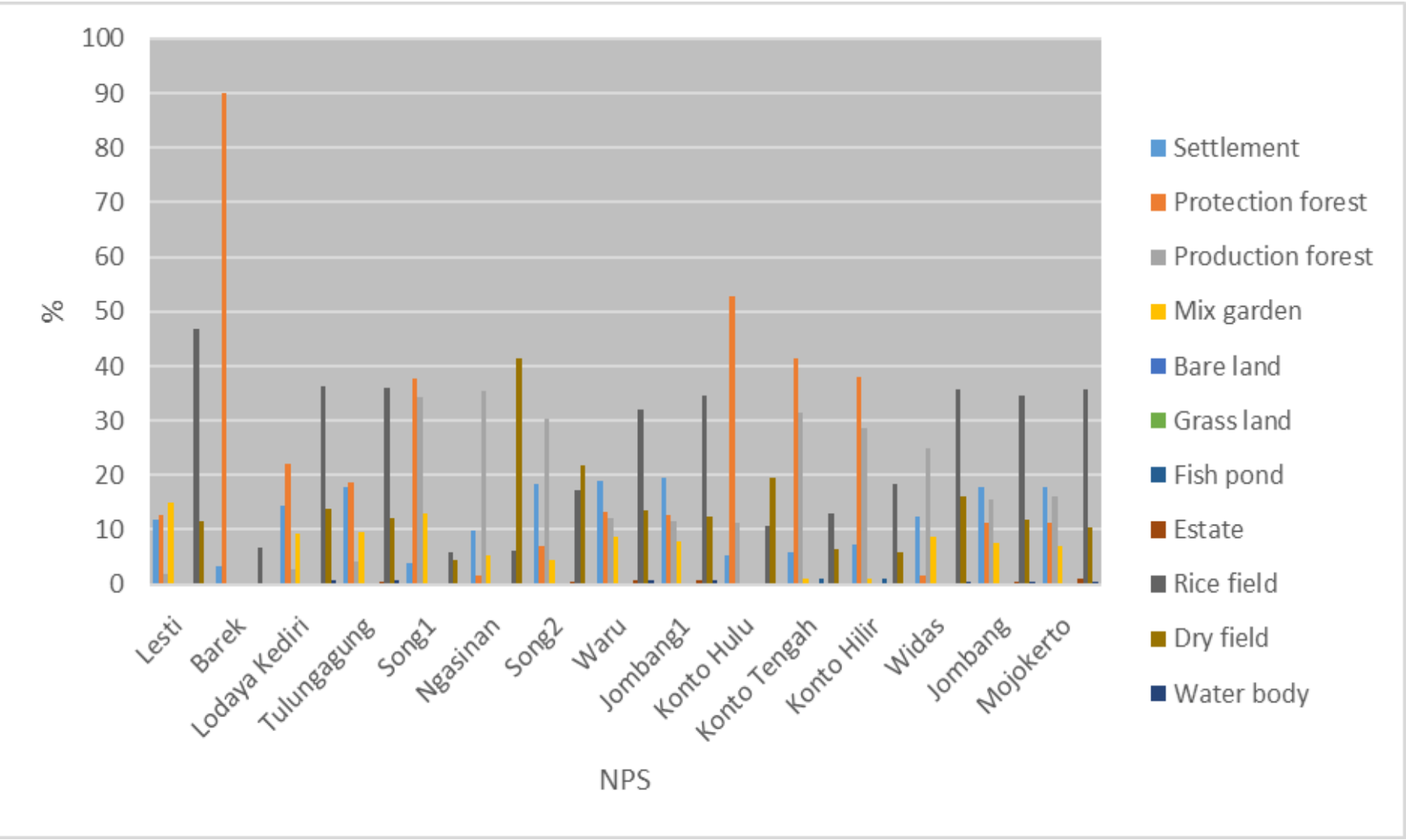

Figure 5. Percentage of Land use/land cover area of each Non-Point Source in Brantas watershed 
Water Quality and Pollution Index (PI)

The results of laboratory analysis of water quality parameters, calculation of pollution indices, and water quality crtiteria are presented in the Table 2 (organic and inorganic chemistry) and Table 3 (physical and biological), while the results of the descriptive analysis of each parameter are presented in Table 4.

The results of laboratory analysis of water quality parameters, calculation of pollution indices, and water quality criteria are presented in Table 2 (organic and inorganic chemistry) and Table 3 (physical and biological), while the results of

Table 2. Average value of organic and inorganic chemistry parameters of each Non-Point Source

\begin{tabular}{|c|c|c|c|c|c|c|c|c|c|}
\hline NPS & $\begin{array}{l}\mathrm{OD} \\
\mathrm{mg} / \mathrm{L}\end{array}$ & $\begin{array}{l}\mathrm{B} \\
\mathrm{ODm} \\
\mathrm{g} / \mathrm{L}\end{array}$ & $\begin{array}{l}\text { Chenol } \\
\mathrm{mg} / \mathrm{L}\end{array}$ & $\begin{array}{l}\text { Free } \\
\text { chlorine } \\
\mathrm{mg} / \mathrm{L}\end{array}$ & $\mathrm{Fe} \mathrm{mg} / \mathrm{L}$ & $\begin{array}{l}\text { Phosphate } \\
\text { mg/L }\end{array}$ & $\begin{array}{l}\text { Nitrate } \\
\mathrm{mg} / \mathrm{L}\end{array}$ & $\begin{array}{l}\text { Nitrite } \\
\mathrm{mg} / \mathrm{L}\end{array}$ & $\begin{array}{l}\text { Deter- } \\
\text { gen } \\
\mathrm{mg} / \mathrm{L}\end{array}$ \\
\hline PP 82/2001, Class III & 6 & 50 & 0.001 & 0.03 & - & 1 & 20 & 0,06 & 0,2 \\
\hline Keduang & 5.1 & 30.35 & $<0.0215$ & 0 & 0.17465 & 0.431 & 1.475 & 0.09305 & 0.0013 \\
\hline Tirtomoyo & 3.8 & 25.7 & $<0.0215$ & 0 & 0.2357 & 0.9669 & 2.055 & 0.03445 & 0.1319 \\
\hline Upper solo & 3.8 & 27.05 & $<0.0215$ & 0 & 0.35405 & 0.2462 & 2.37 & 0.12565 & 0 \\
\hline Alang & 3.8 & 27.6 & $<0.0215$ & 0 & 0.131 & 0.48705 & 2.81 & 0.0654 & 0 \\
\hline Temon & 4.6 & 33.7 & $<0.0215$ & 0 & 0.20425 & 1.47805 & 2.455 & 0.24145 & 0.0289 \\
\hline Wuryantoro & 3.8 & 18.9 & $<0.0215$ & 0 & 0.5864 & 0.34145 & 1.47 & 0.04825 & 0.0066 \\
\hline Nguter & 3.3 & 22.4 & $<0.0215$ & 0 & 0.38895 & 0.33695 & 1.63 & 0.05975 & 0.1053 \\
\hline Mungkung & 13 & 43 & 0.01325 & 0 & 1.55625 & 1.3905 & 6.73 & 0.3753 & 0.0547 \\
\hline Kenatan & 9.5 & 24.1 & $<0.0215$ & 0.15 & 0.73735 & 1.3611 & 4.14 & 0.19105 & 0.00125 \\
\hline Bengawan Solo & 11.25 & 48.55 & $<0.0215$ & 0.05 & 1.20295 & 5.8205 & 4.94 & 0.0365 & 0.03025 \\
\hline Pulosari & 9.3 & 36.7 & 0.0221 & 0.1 & 0.20935 & 1.1138 & 4.855 & 0.2584 & 0.0289 \\
\hline Samin & 15.25 & 36.65 & 0.0211 & 0.05 & 1.51825 & 0.89885 & 1.24 & 0.32375 & 0.02705 \\
\hline Dengkeng & 10.8 & 34.35 & $<0.0215$ & 0.2 & 0.12 & 3.0502 & 4.135 & 0.2451 & $<0.0002$ \\
\hline Lesti, Malang & 2.95 & 25.75 & 0 & 0.25 & 1.4239 & 0.8272 & 16.005 & 0.08375 & 0.01085 \\
\hline Barek Blitar & 2.75 & 18.75 & 0 & 0.2 & 0.7442 & 0.29965 & 487 & 0.19025 & 0.01205 \\
\hline Lodoyo & 2.55 & 17.45 & 0 & 0.2 & 2.90725 & 0.8057 & 12.055 & 0.01955 & 0.0081 \\
\hline Brantas Tulungagung & 3.85 & 16.7 & 0 & 0.25 & 3.51335 & 0.47725 & 5.615 & 0.02835 & 0.06415 \\
\hline Song 1 Tulungagung & 7.65 & 23.2 & 0 & 0.25 & 7.9125 & 3.8 & 1.86 & 0.1003 & 0.06325 \\
\hline Ngasinan, Trenggalek & 8 & 32.25 & 0 & 0.2 & 3.46335 & 2.6083 & 4.435 & 0.04785 & 0.0065 \\
\hline Song 2 Tulungagung & 8.95 & 32.65 & 0 & 0.35 & 2.95745 & 0.2685 & 6.095 & 0.3584 & 0.07425 \\
\hline $\begin{array}{l}\text { Bendung Waru } \\
\text { Kediri }\end{array}$ & 3.75 & 19.85 & 0.01915 & 0.55 & 0.0806 & 0.9362 & 11.105 & 0.02535 & 0.0286 \\
\hline Brantas Jombang I & 3.35 & 15.4 & 0.02995 & 0.45 & 0.5815 & 1.4029 & 12.545 & 0.0485 & 0.04695 \\
\hline $\begin{array}{l}\text { Konto, Ngantan, } \\
\text { Malang }\end{array}$ & 4.4 & 37.85 & 0.0116 & 0.15 & 3.18575 & 1.3027 & 20.415 & 1.6892 & 0.01895 \\
\hline Konto Tengah & 16.3 & 31.3 & 0.02505 & 0.4 & 1.7141 & 2.4625 & 6.475 & 0.0577 & 0.08245 \\
\hline Konto Hilir & 4.8 & 22.8 & 0.03585 & 0.45 & 0.3199 & 0.8068 & 15.855 & 0.09445 & 0.02655 \\
\hline Widas Nganjuk & 3.7 & 21.9 & 0,0216 & 0.45 & 0.3118 & 0.92045 & 5.705 & 0.06545 & 0.025 \\
\hline Brantas Jombang II & 3.8 & 19.35 & 0,0221 & 0.6 & 0.1227 & 1.663 & 11.12 & 0.09665 & 0.13595 \\
\hline Mojokerto 1 & 1.85 & 17.1 & 0 & 0.05 & 1.76215 & 0.67511 & 11.055 & 0.10485 & 0.0158 \\
\hline
\end{tabular}


Table 3. The average value of physical and biological parameters of each Non-Point Source

\begin{tabular}{|c|c|c|c|c|}
\hline NPS & $\begin{array}{c}\text { TSS } \\
\mathrm{mg} / \mathrm{L}\end{array}$ & $\begin{array}{l}\text { TDS } \\
\mathrm{mg} / \mathrm{L}\end{array}$ & $\begin{array}{c}\text { Turbidity } \\
\text { NTU }\end{array}$ & $\begin{array}{l}\text { Total E. coli } \\
\text { / 100mL }\end{array}$ \\
\hline PP 82/2001, Class III & 1000 & 400 & 25 & 10000 \\
\hline Keduang & 78 & 149 & 103.5 & 270 \\
\hline Tirtomoyo & 171.5 & 189,5 & 211.5 & 800 \\
\hline Upper solo & 76 & 192,5 & 107 & 800 \\
\hline Alang & 209.5 & 211 & 278.5 & 0 \\
\hline Temon & 14.075 & 215 & 483.5 & 11.55 \\
\hline Wuryantoro & 42.5 & 200 & 43.5 & 0 \\
\hline Nguter & 103 & 486,5 & 121 & 0 \\
\hline Mungkung & 55.5 & 118 & 341 & 1,700 \\
\hline Kenatan & 29.5 & 105 & 70.5 & 230,000 \\
\hline Bengawan Solo & 124 & 120,5 & 227.5 & 24,000 \\
\hline Pulosari & 60 & 99 & 130 & 16,000 \\
\hline Samin & 77 & 104 & 153 & 540,000 \\
\hline Dengkeng & 76 & 151 & 105 & 230,000 \\
\hline Lesti, Malang & 77.5 & 152 & 92.5 & 1,600 \\
\hline Barek Blitar & 11.5 & 76 & 24 & 16,000 \\
\hline Lodoyo & 55 & 101 & 72 & 23 \\
\hline Brantas Tulungagung & 85.5 & 158 & 103.5 & 260 \\
\hline Song 1 Tulungagung & 483 & 39 & 169.45 & 1,600 \\
\hline Ngasinan, Trenggalek & 456.5 & 112 & 74.6 & 260 \\
\hline Song 2 Tulungagung & 76 & 70 & 135 & 920 \\
\hline Bendung Waru Kediri & 97 & 106 & 72.5 & 94 \\
\hline Brantas Jombang I & 149 & 129 & 153.5 & 110 \\
\hline Konto, Ngantan, Malang & 42 & 118 & 77 & 16,000 \\
\hline Konto Tengah & 84 & 992 & 2891.5 & 16,000 \\
\hline Konto Hilir & 94.5 & 353.5 & 584.5 & 79 \\
\hline Widas Nganjuk & 115 & 114.5 & 77.5 & 12 \\
\hline Brantas Jombang II & 117 & 169.5 & 160.5 & 46 \\
\hline Mojokerto 1 & 72.5 & 170 & 80.5 & 94 \\
\hline
\end{tabular}

Table 4. Statistical description of water quality data

\begin{tabular}{lrrrrr}
\hline Parameters & \multicolumn{1}{c}{ Minimum } & \multicolumn{1}{c}{ Maximum } & \multicolumn{1}{c}{ Mean } & \multicolumn{1}{c}{ Std. Deviation } & Variance \\
\hline TSS $(\mathrm{mg} / \mathrm{l})$ & 11.50 & 483.00 & $1.1188 \mathrm{E} 2$ & 110.11839 & $1.213 \mathrm{E} 4$ \\
TDS $(\mathrm{mg} / \mathrm{l})$ & 39.00 & 992.00 & $1.8577 \mathrm{E} 2$ & 180.92246 & $3.73 \mathrm{E} 4$ \\
BOD $(\mathrm{mg} / \mathrm{l})$ & 1.85 & 16.30 & 6.2839 & 4.02221 & 16.178 \\
COD $(\mathrm{mg} / \mathrm{l})$ & 15.40 & 48.55 & 27.1911 & 8.55674 & 73.218 \\
Phenol $(\mathrm{mg} / \mathrm{l})$ & 0.00 & 0.04 & 0.0079 & 0.01158 & 0.000 \\
Chlorine $(\mathrm{mg} / \mathrm{l})$ & 0.00 & 0.60 & 0.1911 & 0.18661 & 0.035 \\
Fe $(\mathrm{mg} / \mathrm{l})$ & 0.08 & 7.91 & 1.3721 & 1.70296 & 2.900 \\
Phosphat $(\mathrm{mg} / \mathrm{l})$ & 0.25 & 5.82 & 1.3087 & 1.20841 & 1.460 \\
Nitrate $(\mathrm{mg} / \mathrm{l})$ & 1.24 & 20.42 & 6.6255 & 5.15271 & 26.550 \\
Nitrite $(\mathrm{mg} / \mathrm{l})$ & 0.02 & 1.69 & 0.1825 & 0.31333 & 0.098 \\
Detergent $(\mathrm{mg} / \mathrm{l})$ & 0.00 & 0.14 & 0.0370 & 0.03887 & 0.002 \\
Turbidity $(\mathrm{NTU})$ & 24.00 & 2891.50 & $2.5514 \mathrm{E} 2$ & 532.26544 & $2.833 \mathrm{E} 5$ \\
E.coli $(/ 100 \mathrm{ml})$ & 0.00 & $5.40 \mathrm{E} 5$ & $3.9167 \mathrm{E} 4$ & $1.14836 \mathrm{E} 5$ & $1.319 \mathrm{E} 10$ \\
\hline
\end{tabular}

Source: Data analyses (2019) 
the descriptive analysis of each parameter are presented in Table 4.

Table 4 shows that the smallest variance is for the Phenol parameter while the biggest is for E. coli. Large variance values indicate that the parameter data varies significantly from one location to another and vice versa. The maximum value of some parameters exceeds the Class III standard of water quality such as TDS, BOD, Phenol, Chlorine, Phosphate,
Nitrite, Nitrate, Detergent, Turbidity, and E. Coli. This causes the water quality at that location to be classified into class IV. Table 5 and 6 show that all NPS water samples have water quality, which is included in Class IV because it is not following Class III and above (Class I and II). The results of PI analysis of each NPS can be seen in Table 3. It shows that, even though they have the same class, however, each has a different PI value with different limiting parameters. The following

Table 5. Pollution levels and its limiting factors at each observation location

\begin{tabular}{|c|c|c|c|}
\hline Lokasi & PI Value & Pollution Level & Limiting parameters \\
\hline \multicolumn{4}{|l|}{ Solo Watershed } \\
\hline Keduang & 2.92 & lightly polluted & turbidity, nitrite \\
\hline Tirtomoyo & 4.01 & lightly polluted & turbidity \\
\hline Upper Solo & 2.98 & lightly polluted & turbidity, nitrite \\
\hline Alang & 4.44 & lightly polluted & turbidity, nitrite \\
\hline Temon & 5.31 & lightly polluted & turbidity, nitrite, phosphate \\
\hline Wuryantoro & 1.58 & lightly polluted & turbidity \\
\hline Nguter & 3.16 & lightly polluted & TDS, turbidity \\
\hline Mungkung & 4.88 & lightly polluted & phenol, phosphate, nitrite, turbidity \\
\hline Kenatan & 5.65 & lightly polluted & BOD, chlorine, phosphate, nitrite, turbidity, E. coli \\
\hline Bengawan Solo & 4.22 & lightly polluted & BOD, chlorine, phosphate, nitrite, E. coli \\
\hline Pulosari & 5.62 & lightly polluted & $\begin{array}{l}\text { BOD, phenol, chlorineine, phosphate, nitrite, turbidity, E. } \\
\text { coli }\end{array}$ \\
\hline Samin & 7.04 & lightly polluted & BOD, phenol, chlorineine, nitrite, turbidity, E. coli \\
\hline Dengkeng & 5.07 & lightly polluted & BOD, phosphate, nitrite, turbidity, E. coli \\
\hline \multicolumn{4}{|l|}{ Brantas watershed } \\
\hline Lesti, Malang & 4.03 & lightly polluted & chlorine, nitrite, turbidity \\
\hline Barek Blitar & 3.68 & lightly polluted & chlorine, nitrite, E. coli \\
\hline Lodoyo & 3.66 & lightly polluted & chlorine, turbidity \\
\hline Brantas Tulungagung & 4.01 & lightly polluted & chlorine, turbidity \\
\hline Song 1 Tulungagung & 4.09 & lightly polluted & BOD, chlorine, nitrite, turbidity \\
\hline Ngasinan, Trenggalek & 3.71 & lightly polluted & BOD, chlorine, phosphorus, turbidity \\
\hline Song 2 Tulungagung & 4.58 & lightly polluted & BOD, chlorine, nitrite, turbidity \\
\hline Bendung Waru Kediri & 5.35 & lightly polluted & phenol, chlorine, turbidity \\
\hline Brantas Jombang I & 6.06 & lightly polluted & phenol, chlorine, phosphate, turbidity \\
\hline Konto, Ngantan, Malang & 6.01 & lightly polluted & phenol, chlorine, phosphate, nitrite, nitrate, turbidity, E. coli \\
\hline Konto Tengah & 8.22 & lightly polluted & TDS, BOD, phenol, chlorine, phosphate, turbidity, E. coli \\
\hline Konto Hilir & 6.37 & lightly polluted & phenol, chlorine, nitrite, turbidity \\
\hline Widas Nganjuk & 5.54 & lightly polluted & phenol, chlorine, nitrite, turbidity \\
\hline Brantas Jombang II & 5.62 & lightly polluted & phenol, chlorine, phosphate, nitrite, turbidity \\
\hline Mojokerto 1 & 2.55 & lightly polluted & chlorine, nitrite, turbidity \\
\hline
\end{tabular}


Table 6. Correlation between PI values with each parameter

Correlations

PI_III TSS TDS BOD COD Phenol Chlorine Fe Phosphat Nitrate Nitrite Detergent Turbidity E.coli

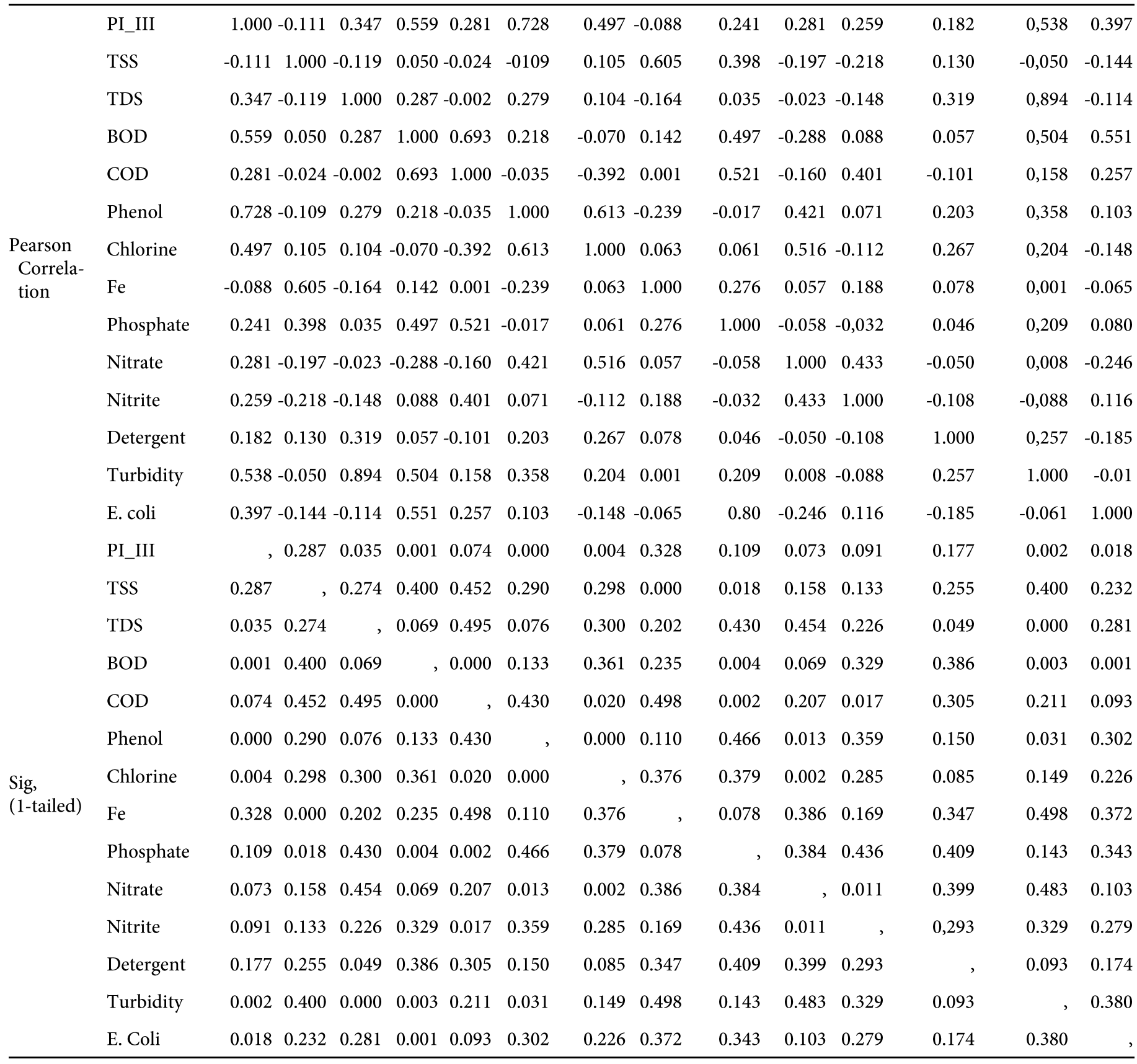

Source: Primary data, 2019

are the results of PI calculations and the limiting factors in each of the observed locations (Table 5).

Based on Table 5 it can be seen that there are various PI values and limiting parameters. Upper Solo watershed has a range of PI values between 1.58 (Wuryantoro) to 7.04 (Samin) with mild and moderate polluted categories, and also the Brantas watershed has the lowest PI value of 2.55 (Mojokerto), and the highest is 8.22 (Konto Tengah) with the mild and moderate contaminated categories. This value indicates that the water quality of Class III does not meet the quality standards, according to PP 82/2001. All sample points are in a polluted condition, both lightly and moderately polluted.
This is due to the many limiting factors in each observation location exceeding the quality standard. Some of the limiting factors include turbidity, nitrite, nitrate, phosphate, TDS, BOD, chlorine, phenol, and E. coli. This result is slightly different from the results of Basuki (2015), the values that exceed the standard values were BOD, COD, NTU, nitrite, detergent and chlorine, while TDS and nitrate were still below the Class III threshold value. The limiting factor at each sampling location cannot be separated from the influence of land use and land cover of its catchments. Various community activities will produce pollutant sources which will ultimately affect water quality (Rezagama et al., 2016). At the sampling location that has many mixed gardens and paddy 
fields, it is known that there are parameters that exceed the quality standards such as phenol, TDS, chlorine, and turbidity. This may be caused by fertilising activities, the use of pesticides and insecticides. Mariyono \& Irham (2001) stated that chemical pesticides commonly used in agricultural activities could cause environmental damage and pollution.

Based on data on land use/land cover, it is known that in areas with the dominant use of paddy field and dry field, land experience intensive management that may cause erosion and will ultimately increase water turbidity. Intensive land management can cause erosion and sedimentation, which accumulates in both the upper and lower slopes (Arianti, Suratman, Martono, \& Suprayogi, 2012). Meanwhile, areas dominated by settlements will have limiting factors such as turbidity, BOD, chlorine, phosphate, Fe, and nitrite. This is due to a large amount of waste entering the water body due to various domestic activities. Hamakonda, Suharto, \& Susanawati (2017) said that domestic activities could cause pollution by BOD and nitrite.

\section{The main parameters of water quality}

Correlation analysis results show that several parameters have a large enough correlation $(>0.50)$ (Table 9) such as, COD-BOD, BOD-Turbidity, COD-Phosphat, TurbidityTDS. These findings are similar to those stated by Basuki (2015). Basuki (2015) found that the strong correlation between COD-BODand BOD-Turbidity.

Multistage regression analysis using the value of PI as a dependent variable and limiting factor as independent variables give results about some of the most influential limiting factors. Table 5 shows the correlation between PI values with each parameter measured.

Based on the Table 3 it can be seen that there is a positive correlation between the value of PI with Phenol and BOD. This is indicated by the high correlation value of 0,728 (Phenol) and 0,559 (BOD). The two parameters also show the percentage value that describes the PI content at the sampling location (Table 4).

Table 9 shows that the value of $\mathrm{R}$ when using phenol alone illustrates the PI value of $72.8 \%$, with a value of $\mathrm{R}$ Square of $53 \%$ (Model 1). If a BOD factor is added, the percentage will increase to $83.6 \%$ with an $\mathrm{R}$ square value of $69.9 \%$ (Model 2). The error value of these two parameters can also be seen in the ANOVA in Table 5. It means that the phenol variable can significantly explain $72.8 \%$ of the Model 1 at a confidence level of 0.05 and so as Model 2, BOD and phenol can significantly explain $83.6 \%$.

The regression coefficient is used to determine the model to be used. Coefficient regression analysis can be seen in Table 6 .

The equations formed from the analysis are: Model 1: PI = $3.952+91.688$ phenol and Model 2: PI $=3.086+80.167$ Phenol +0.152 BOD. Both models can be used to predict PI based on phenol and BOD values. Model 1 only requires phenol as a parameter, while Model 2 requires phenol and BOD. Model 2 has a higher $\mathrm{R}$ square value based on $\mathrm{R}$ square analysis (Table 4). By knowing the phenol and BOD value, the water quality of a watershed can be predicted.

The use of phenol and BOD as PI estimator variables are in line with some researches finding. Phenol is a dangerous pollutant when found in water bodies (Kahn, Li, \& Zhao, 2015). Effendi (2003) stated that phenol in water bodies would cause changes like water that can be toxic to aquatic biota. Jauhari \& Thamrin (2012) added that phenol is one of the pollutant sources that have an impact on the environment and is toxic to the human body. Apart from industrial activities, the phenol content in water bodies is also caused by the natural decomposition of organic matter and agricultural activities (Zhong, Wang, \& Wang, 2017). Yogafanny (2015) stated that phenol could come from the decay of organic materials such as wood, twigs, or other organic waste, as well as the remaining animal feed and the rest of the or-

Table 7. R square value of PI contents

\begin{tabular}{ccccc}
\hline Model & $\mathrm{R}$ & R Square & Adjusted R Square & Std, Error of the Estimate \\
\hline 1 & $0.728^{\mathrm{a}}$ & 0.530 & 0.512 & 1.01819 \\
2 & $0.836^{\mathrm{b}}$ & 0.699 & 0.675 & 0.83156 \\
\hline
\end{tabular}

Remarks: a. Predictors: (Constant), Phenol; b. Predictors: (Constant), Phenol, BOD

Table 8. Analysis of Variance (ANOVA)

\begin{tabular}{|c|c|c|c|c|c|c|}
\hline & Model & Sum of Squares & $\mathrm{df}$ & Mean Square & $\mathrm{F}$ & Sig. \\
\hline \multirow{3}{*}{1} & Regression & 30.424 & 1 & 30.424 & 29.347 & $0.000^{\mathrm{a}}$ \\
\hline & Residual & 26.954 & 26 & 1.037 & & \\
\hline & Total & 57.378 & 27 & & & \\
\hline \multirow{3}{*}{2} & Regression & 40.091 & 2 & 20.046 & 28.989 & $0.000^{\mathrm{b}}$ \\
\hline & Residual & 17.287 & 25 & 0.691 & & \\
\hline & Total & 57.378 & 27 & & & \\
\hline
\end{tabular}

Remark: a. Predictors: (Constant), Phenol; b. Predictors: (Constant), Phenol, BOD 
Table 9. Coefficients regression

\begin{tabular}{|c|c|c|c|c|c|c|}
\hline & \multirow{2}{*}{ Model } & \multicolumn{2}{|c|}{ Unstandardized Coefficients } & Standardized Coefficients & \multirow{2}{*}{$\mathrm{t}$} & \multirow{2}{*}{ Sig. } \\
\hline & & B & Std. Error & Beta & & \\
\hline \multirow{2}{*}{1} & (Constant) & 3.952 & 0.235 & & 16.853 & 0.000 \\
\hline & Phenol & 91.688 & 16.925 & 0.728 & 5.417 & 0.000 \\
\hline \multirow{3}{*}{2} & (Constant) & 3.086 & 0.301 & & 10.263 & 0.000 \\
\hline & Phenol & 80.167 & 14.162 & 0.637 & 5.661 & 0.000 \\
\hline & BOD & 0.152 & 0.041 & 0.421 & 3.739 & 0.001 \\
\hline
\end{tabular}

Remark: Dependent Variable: PI_III

ganic fertiliser which dissolves and enters the water body. The number of activities that have the potential to produce phenol will cause an increase in PI values. This shows that phenol can be a parameter for monitoring and evaluating the health of a watershed. Also, Aufa (2017) and Ontañon, González, \& Agostini (2015) stated that phenol becomes the primary concern Environmental Protection Agency (EPA) and Canada's National Pollutant Release Inventory (NPRI). Moreover, Villegas et al. (2016) stated that phenol is a priority pollutant in water because it is hazardous even in low amounts.

$\mathrm{BOD}$ is an important parameter used in water quality analysis (Jouanneau et al. 2014; Gomolka, Twarog, Zeslawska, Lewicki, \& Kwater, 2017) and the value of Water Quality Index (Kumar, Gupta, Kumar, \& Sharma, 2014). BOD analysis is used to determine the dissolved oxygen content needed by organisms to decompose organic matter in water and is a potential pollutant in observing water quality (Ahmed \& Shah, 2015; Kurnaz et al., 2016; Lee \& Nikraz, 2015). Basuki (2015) revealed parameters BOD can represent $\mathrm{COD}, \mathrm{KMnO}_{4}$, turbidity, nitrite, chlorineide, colour, and sulphate parameters.

\section{Conclusion}

The water pollution index shows the level of pollution in a water body. Water quality analysis is essential to find out the pollution index in the water body. A large number of parameters needed for water quality analysis is an obstacle in assessing water quality in a watershed. The equations that can be used to predict the pollution index are Model 1: PI = $3.952+91.688$ Phenol and Model $2:$ PI $=3.086+80.167$ Phenol +0.152 BOD. To selects the most appropriate model, model validation is necessary. Model validation uses other water quality data from the deferent area which has similar characters. For the present, phenol and/or BOD can be used to predict the pollution index in the watersheds which have similar characters with the study area. It is hoped that the simplification of these parameters can facilitate the observation of the health of water bodies in a watershed.

\section{Acknowledgement}

Thank you to the WMTC Solo for the opportunity provided by facilitating the research budget so that this research can run smoothly. Gratitude is also conveyed to researchers (Rahardyan Nugroho Adi and Pamungkas Buana Putera) and technician (Edi Sulasmiko) who have helped researchers in the field.

\section{References}

Ahmed, A. A. M., \& Shah, S. M. A. (2015). Application of adaptive neuro - fuzzy inference system ( ANFIS ) to estimate the Biochemical Oxygen Demand ( BOD ) of Surma River. Journal of King Saud University-Engineering Sciences, 29 (February), 237-234. https://doi.org/10.1016/ j.jksues.2015.02.001

Arianti, F. D., Suratman, Martono, E., \& Suprayogi, S. (2012). Dampak pengelolaan Lahan Pertanian Terhadap Hasil Sedimen di DAS Galeh Kabupaten Semarang. Jurnal Manusia Dan Lingkungan, 19(3), 238-246.

Aufa, R. (2017). Teknik penyisihan Phenol dari air limbah, (December). https://doi.org/10.5281/zenodo.1133812

Bappenas. Sinergitas Pembangunan Sektor Lingkungan Hidup dan Kehutanan (2015). Jakarta.

Basuki, T. M. (2015). Penyederhanaan Parameter Kualitas Air Untuk Monitoring Dan Evaluasi Kinerja Daerah Aliran Sungai. Forest Rehabilitation Journal, 3(1), 13-21.

Darmawan, A., Sulardiono, B., \& Haeruddin. (2018). Analisis Kesuburan Perairan Berdasarkan Kelimpahan Fitoplankton, Nitrat dan Fosfat di Perairan Sungai bengawan Solo Kota Surakarta. Journal of Maquares, 7(1), 1-8.

Ding, J., Jiang, Y., Fu, L., Liu, Q., Peng, Q., \& Kang, M. (2015). Impacts of Land Use on Surface Water Quality in a Subtropical River Basin: A Case Study of the Dongjiang River Basin, Southeastern China. Water, 7, 4427-4445. https:// doi.org/10.3390/w7084427

Dirjen RLPS. Peraturan Direktur Jenderal RLPS No: P.04/VSET/2009 (2009). Jakarta.

Effendi, H. (2016). Evaluation of water quality status of Ciliwung River based on Pollution Index. In 36th Annual Conference of the International Association for Impact Assessment (pp. 16). Aichi-Nagoya, Japan.

Effendi, H., Muslimah, S., \& Permatasari, P. A. (2018). Relationship between land use and water quality in Pesanggrahan River. Earth and Environmental Science PAPER, 149(1-20). https:// doi.org/10.1088/1755-1315/149/1/012022

Effendi, H., Sabila, M. F., \& Setiawan, Y. (2018). Correlation Between Water Quality and Land Use Change in Ciliwung. Nature Environment and Pollution Technology Journal, 17 (1), 139-144.

Effendi, H., \& Wardiatno, Y. (2015). Water quality status of Ciambulawung River, Banten Province, based on pollution index and NSF-WQI. Procedia Environmental Sciences, 24, 228237. https://doi.org/10.1016/j.proenv.2015.03.030

Gomolka, Z., Twarog, B., Zeslawska, E., Lewicki, A., \& Kwater, T. 
(2017). Using artificial neural networks to solve the problem represented by BOD and DO indicators. Water, 10(1), 1-26. https://doi.org/10.3390/w10010004

Hamakonda, U. A., Suharto, B., \& Susanawati, L. D. (2017). Analisis Kualitas Air dan Beban Pencemar Air Pada Sub DAS Boentuka Kabupaten Timor Tengah Selatan. Jurnal Teknologi Pertanian Andalas, 23(1), 56-67.

Hefni Effendi. (2003). Telaah Kualitas Air. Yogyakarta: Kanisius.

Hidup, M. N. L. Keputusan Menteri Negara Lingkungan Hidup No: 115 Tahun 2003 (2003). Jakarta.

Huang, J., Zhan, J., Yan, H., Wu, F., \& Deng, X. (2013). Evaluation of the Impacts of Land Use on Water Quality: A Case Study in The Chaohu Lake Basin. The Scientific World Journal, 2013, 1-7. https://doi.org/10.1155/2013/329187

Jariyah, nur ainun. (2019). Evaluasi Kinerja Sosial Ekonomi DAS Brantas Berdasarkan Penerapan P61/MENHUT-II/2014. Jurnal Sosial Dan Ekonomi Kehutanan, 16(2), 95-114. https://doi.org/http://dx.doi.org/10.20886/ jpsek.2019.16.2.95-114

Jariyah, N. A., \& Pramono, I. B. (2018). Kerentanan Sosial Ekonomi Dan Biofisik Daerah Aliran Sungai Solo. Jurnal Penelitian Pengelolaan Daerah Aliran Sungai, 2(2), 89-110. https:// doi.org/doi https://doi.org/10.20886/jppdas.2018.2.2.89-110

Jauhari, A., \& Thamrin, G. A. R. (2012). Pemanfaatan Lumpur Aktif dalam mereduksi Phenol. Jurnal Hutan Tropis, 13(1), 18-26.

Jouanneau, S., Recoules, L., Durand, M. J., Boukabache, A., Picot, V., Primault, Y., ... Thouand, G. (2014). Methods for assessing biochemical oxygen demand (BOD): A review. $W a-$ ter Research, 49(1), 62-82. https://doi.org/10.1016/ j.watres.2013.10.066

Kahn, M. E., Li, P., \& Zhao, D. (2015). Water pollution progress at borders: The role of changes in China's political promotion incentives. American Economic Journal: Economic Policy, 7 (4), 223-242. https://doi.org/10.1257/pol.20130367

Kumar, K., Gupta, N., Kumar, V., \& Sharma, S. (2014). Water Quality Assessment of Pahuj River using Water Quality Index at Unnao Balaji , M . P ., India. International Journal of Sciences: Basic and Applied Research, 4531(December), 241-250.

Kurnaz, A., Mutlu, E., \& Uncumusaoğlu, A. A. (2016). Determination of Water Quality Parameters and Heavy Metal Content in Surface Water of Çiğdem Pond ( Kastamonu / Turkey ). Turkish Journal of Agriculture - Food Science and Technology, 4(10), 907-913.

Lee, A. H., \& Nikraz, H. (2015). Overview of waste management performance of industrial sectors by selected Asian countries: current practices and issues. In International Proceedings of Chemical, Biological and Environmental Engineering (Vol. 88, pp. 89-94). https://doi.org/10.7763/ipcbee

Mariyono, J., \& Irham. (2001). Usaha Menurunkan Penggunaan Pestisida Kimia Dengan Program Pengendalian Hama Terpadu. Manusia Dan Lingkungan, VIII(1), 30-36.

Mutlu, E., \& Uncumusaoğlu, A. A. (2017). Investigation of the Water Q uality of Alpsarı Pond ( Korgun - Çankırı ). Turkish Journal of Fisheries and Aquatic Sciences, 17, 1231-1243. https://doi.org/10.4194/1303-2712-v17

Nazir, R., Khan, M., Masab, M., Rehman, H. U., Rauf, N. U., Shahab, S., ... Shaheen, Z. (2015). Accumulation of heavy metals $(\mathrm{Ni}, \mathrm{Cu}, \mathrm{Cd}, \mathrm{Cr}, \mathrm{Pb}, \mathrm{Zn}, \mathrm{Fe})$ in the soil, water and plants and analysis of physico-chemical parameters of soil and water collected from Tanda Dam Kohat. Journal of Pharmaceutical Sciences and Research, 7(3), 89-97.

Ontañon, O. M., González, P. S., \& Agostini, E. (2015). Optimization of simultaneous removal of $\mathrm{Cr}(\mathrm{VI})$ and phenol by a native bacterial consortium: Its use for bioaugmentation of co-polluted effluents. Journal of Applied Microbiology, 119 (4), 1011-1022. https://doi.org/10.1111/jam.12913

Paimin, Sukresno, \& Purwanto. (2010). Sidik Cepat Degradasi SUB DAS. Surakarta: BPK Solo.
Permatasari, P. A., Setiawan, Y., \& Effendi, H. (2017). The effect of

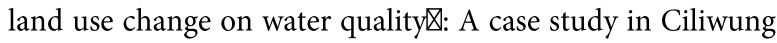
Watershed. Earth and Environmental Science, 2017 (January), 1-9. https://doi.org/10.1088/1755$1315 / 54 / 1 / 012026$

Permatasari, P. A., Setiawan, Y., Khairiah, R. N., \& Effendi, H. (2017). The effect of land use change on water quality: A case study in Ciliwung Watershed. Journal of Physics: Conference Series Earth and Environmental Science, 54, 1-7. https:// doi.org/10.1088/1742-6596/755/1/011001

Rezagama, A., Tamlikha, A., Lingkungan, J. T., Teknik, F., Diponegoro, U., Hidup, L., ... Water, A. (2016). Identifikasi Pencemar Waduk Manggar Kota Balikpapan. Jurnal Pengembangan Kota, 4(1), 40-48. https://doi.org/10.14710/jpk.4.1.40 $-48$

RI, kementerian S. N. Peraturan Pemerintah Republik Indonesia No. 37 Tahun 2012 (2012). Jakarta.

Roosmini, D., Septiono, M. A., Putri, N. E., Shabrina, H. M., Salami, I. R. S., \& Ariesyady, H. D. (2018). River Water Pollution Condition in Upper Part of Brantas River and Bengawan Solo River River. In The 4th International Seminar on Sustainable urban Development (pp. 1-6). Jakarta.

Shukla, A. K., Shukla, S., Ojha, C. S. P., Buytaert, W., Mijic, A., Pathak, S., \& Garg, R. D. (2018). Population growth, land use and land cover transformations, and water quality nexus in the Upper Ganga River basin. Hydrology and Earth System Sciences, 22(9), 4745-4770. https://doi.org/10.5194/hess-224745-2018

Singh, S., Brandenburg, N., Ahiablame, L., Gonzalez, A., Kjaersgaard, J., Trooien, T. P., \& Kumar, S. (2017). Response of Winter Manure Application on Surface Runoff Water Quantity and Quality from Small Watersheds in South Dakota. Water Air Soil Pollut (2017), 2017, 228-389. https:// doi.org/10.1007/s11270-017-3572-5

Souza, A. L. T. De, Fonseca, D. G., Libório, R. A., \& Tanaka, M. O. (2013). Forest Ecology and Managemen $t$ Influence of riparian vegetation and forest structure on the water quality of rural low-order streams in SE Brazil. Forest Ecology and Managemen T, 298, 12-18. https://doi.org/10.1016/ j.foreco.2013.02.022

Villegas, L. G. C., Mashhadi, N., Chen, M., Mukherjee, D., Taylor, K. E., \& Biswas, N. (2016). A Short Review of Techniques for Phenol Removal from Wastewater. Current Pollution Reports, 2, 157-167. https://doi.org/10.1007/s40726-016-0035-3

Wahyuningrum, N., \& Basuki, T. M. (2019). Analisis Kekritisan Lahan Untuk Perencanaan Rehabilitasi Lahan DAS Solo Bagian Hulu. Jurnal Penelitian Pengelolaan Daerah Aliran Sungai, 3(1), 27-44. https://doi.org/doi https:// doi.org/10.20886/jppdas.2019.3.1.27-44

Wahyuningrum, N., \& Pramono, I. B. (2013). The Potential of Forest Buffer to Prevent Stream from Water Pollutants: a Case Study in Grojokan Sewu Sub-Watershed, Karanganyar District, Central Java. Indonesian Journal of Forestry Research, 10(2), 101-109. https://doi.org/10.20886/ijfr.2013.10.2.101109

Wahyuningrum, N., \& Putra, B. (2019). Analisis Lahan Terdegradasi DAS Brantas Dan Upaya Penanggulangannya Untuk Mendukung Rehabilitasi Lahan. Jurnal Penelitian Kehutanan Wallacea, 8, 135-145. https://doi.org/http:// dx.doi.org/10.18330/jwallacea.2019.vol8iss2pp135-145

Yogafanny, E. (2015). Pengaruh Aktifitas Warga di Sempadan Sungai terhadap Kualitas Air Sungai Winongo. Jurnal Sains Dan Teknologi Lingkungan, 7(1), 41-50.

Zhong, W., Wang, D., \& Wang, Z. (2017). Distribution and potential ecological risk of 50 phenolic compounds in three rivers in Tianjin , China. Environmental Pollution, 235 (December), 121-128. https://doi.org/10.1016/ j.envpol.2017.12.037 